\title{
Intertrigo of streptococcal aetiology: a different kind of diaper dermatitis
}

\author{
Susana Castilho, Sofia Ferreira, Fabiana Fortunato, Sara Santos
}

Department of Pediatrics, Centro Hospitalar do Oeste, Caldas da Rainha, Portugal

\section{Correspondence to} Dr Sofia Ferreira, sofia.su.ferreira@gmail.com

Accepted 1 March 2018

\section{DESCRIPTION}

A 3-month-old infant presented with a 3-day history of an intertriginous eruption. His previous history was irrelevant and his last vaccination was at 2 months old according to the Portuguese immunisation schedule.

No other family members were affected and the child was otherwise well. Physical examination revealed an exuberant area of erythema and maceration of the inguinal folds and genitals (figures 1 and 2 ). This rash was bright red in colour and had well-defined borders. No satellite lesions were present.

Bacterial culture of the affected region was obtained by a skin swab, and empirical treatment with oral flucloxacillin was started, admitting probable bacterial aetiology. The culture yielded a growth of group A beta-haemolytic streptococci sensitive to penicillin. Since the eruption had already started improving, treatment with flucloxacillin was continued with complete resolution of the intertrigo.

Intertrigo is an inflammatory dermatitis of the skin folds, induced by friction and moisture, to which small children are particularly susceptible. It is frequently associated with infection, most commonly candidal, but other agents may be involved, in particular group A beta-haemolytic streptococci or Staphylococcus aureus. ${ }^{1}$

Group A beta-haemolytic streptococci infection is still an under-recognised cause of intertrigo. It usually manifests as a well-demarcated, bright-red erythema and maceration of the skin folds, with absence of satellite lesions and a distinct foul odour. The infection can induce the formation of psoriasiform guttate skin lesions (scaly erythematous islands), which may resemble satellite lesions. The child may also present with low-grade fever and irritability. ${ }^{1-3}$ Although differential diagnosis with candidal dermatitis can be challenging, these clinical features can help to

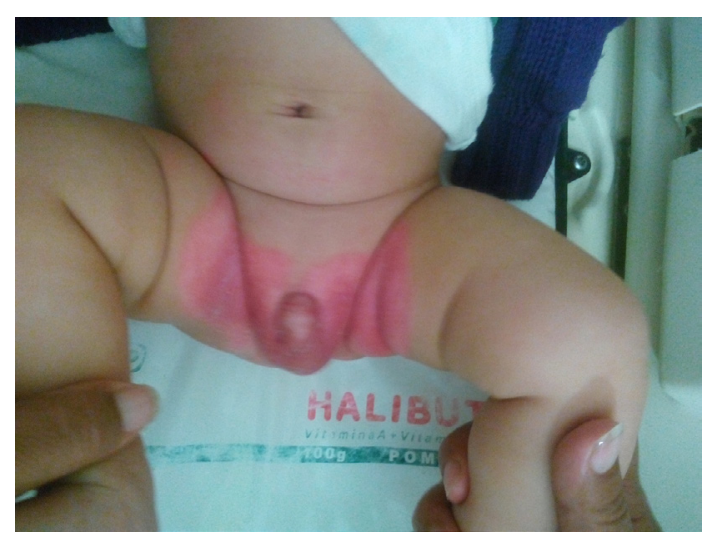

Figure 1 Intertriginous eruption on the third day after initial appearance.

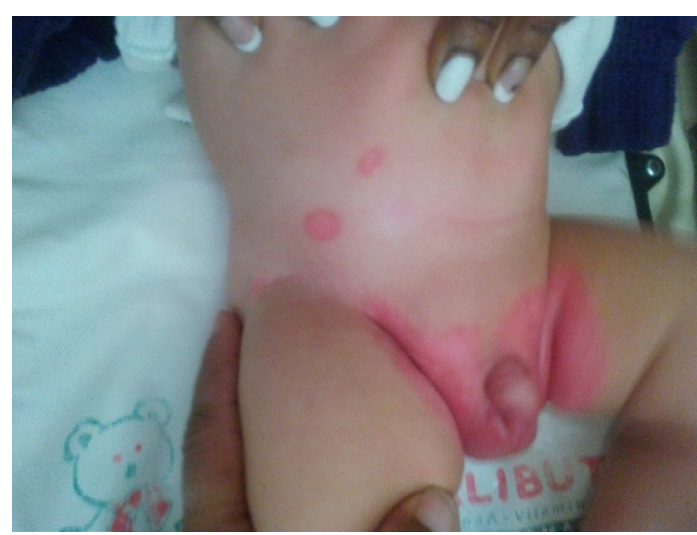

Figure 2 Intertriginous eruption on the third day after initial appearance.

differentiate it. Antibiotic therapy is generally curative. Cutaneous group A beta-haemolytic streptococci infections are not associated with complications like rheumatic fever or acute glomerulonephritis. ${ }^{1}$

\section{Learning points}

- Intertrigo is an inflammatory dermatitis of the skin folds commonly observed in small children, which is frequently aggravated by fungal, bacterial or viral infection.

- Even though candidal dermatitis is the most common infectious complication of intertrigo, other aetiologies such as group A streptococci should not be forgotten, especially in the presence of specific clinical features and when topical antifungal treatment fails.

- Streptococcal intertrigo usually manifests as an intense bright-red erythema and maceration of the skin folds, with a distinct foul odour and no satellite lesions.

Contributors SC contributed to the case report data acquisition (pictures and clinical history), analysis and interpretation, paper drafting and revision of the manuscript. SF contributed to the case report data acquisition (pictures and clinical history), analysis and interpretation, paper drafting and revision of the manuscript. FF contributed to the case report data acquisition (pictures and clinical history), analysis and interpretation and participated in the revision of the manuscript. SS contributed to the case report data acquisition (pictures and clinical history), analysis and interpretation and participated in the revision of the manuscript. All authors approved the final version of the manuscript and agreed to be accountable for the article and to ensure that all questions regarding the accuracy or integrity of the article are investigated and resolved.

Funding The authors have not declared a specific grant for this research from any funding agency in the public, commercial or not-for-profit sectors. 
Competing interests None declared.

Patient consent Guardian consent obtained.

Provenance and peer review Not commissioned; externally peer reviewed.

(c) BMJ Publishing Group Ltd (unless otherwise stated in the text of the article) 2018. All rights reserved. No commercial use is permitted unless otherwise expressly granted.

\section{REFERENCES}

1 Honig PJ, Frieden IJ, Kim HJ, et al. Streptococcal intertrigo: an underrecognized condition in children. Pediatrics 2003:112:1427-9.

2 Herbst RA. Perineal streptococcal dermatitis/disease. Am I Clin Dermatol 2003:4:555-60

3 Shin HT. Diaper dermatitis that does not quit. Dermatol Ther 2005;18:124-35.

Copyright 2018 BMJ Publishing Group. All rights reserved. For permission to reuse any of this content visit http://group.bmj.com/group/rights-licensing/permissions.

BMJ Case Report Fellows may re-use this article for personal use and teaching without any further permission.

Become a Fellow of BMJ Case Reports today and you can:

- Submit as many cases as you like

- Enjoy fast sympathetic peer review and rapid publication of accepted articles

Access all the published articles

Re-use any of the published material for personal use and teaching without further permission

For information on Institutional Fellowships contact consortiasales@bmjgroup.com

Visit casereports.bmj.com for more articles like this and to become a Fellow 